This is an electronic reprint of the original article. This reprint may differ from the original in pagination and typographic detail.

Author(s): Sivunen, Anu

Title: Työelämän teknologiavälitteisen vuorovaikutuksen tutkimus

Year: $\quad 2017$

Version:

Please cite the original version:

Sivunen, A. (2017). Työelämän teknologiavälitteisen vuorovaikutuksen tutkimus.

Prologi : puheviestinnän vuosikirja, 2017, 56-59.

All material supplied via JYX is protected by copyright and other intellectual property rights, and duplication or sale of all or part of any of the repository collections is not permitted, except that material may be duplicated by you for your research use or educational purposes in electronic or print form. You must obtain permission for any other use. Electronic or print copies may not be offered, whether for sale or otherwise to anyone who is not an authorised user. 


\title{
Virkaanastujaisesitelmä
}

Prologi - puheviestinnän vuosikirja 2017

\section{Työelämän teknologiavälitteisen vuorovaikutuksen tutkimus}

\author{
Anu Sivunen \\ Puheviestinnän professori \\ Jyväskylän yliopisto, Kieli- ja viestintätieteiden laitos \\ anu.e.sivunen@jyu.fi
}

Uuden professorin juhlaluento, 7.12.2016, Jyväskylän yliopisto

Työelämä on ollut viime vuosikymmeninä suurissa muutoksissa. Globalisaatio on mahdollistanut organisaatioiden kansainvälistymisen ja yhteistyö- ja alihankintasopimusten solmimisen ympäri maailmaa. Viestintäteknologian kehittyminen on edistänyt tätä kansainvälistymistä mahdollistamalla työntekijöiden vuorovaikutuksen maantieteellisten rajojen yli ja osin myös aikaeroista riippumatta. Uusia teknologioita otetaan käyttöön organisaatioissa jatkuvasti, ja viime vuosina ovat myös työelämässä yleistyneet muun muassa sosiaalisen median työkalut. Teknologian kehittyminen on tuonut työelämään myös uusia työn tekemisen muotoja. Virtuaalitiimit, etätyö, joustava ja liikkuva työ ovat esimerkkejä siitä, miten työtä tehdään yhdessä, mutta eri paikoista käsin, joskus eriaikaisesti ja joskus samaan aikaan työskennellen, tietyssä paikassa tai paikasta toiseen liikkuen ja esimerkiksi matkapuhelinten ja kannettavien tietokoneiden avulla työtä tehden. Työelämää luonnehtiikin nykyisin vahvasti teknologiavälitteinen vuorovaikutus, joka on ollut viestinnän alan keskeisiä tutkimuskohteita jo useamman vuosikymmenen ajan. Teknologiavälitteisellä vuorovaikutuksella tarkoitetaan yleensä tekstiin, ääneen, kuviin tai videokuvaan perustuvaa vuorovaikutusta, jossa on osallisina kaksi tai useampia viestintäosapuolia tietokoneiden ja internet-yhteyden välityksellä.

Esittelen puheenvuorossani yhtäältä työelämän teknologiavälitteisen vuorovaikutuksen tutkimusperinnettä ja tämänhetkisiä tutkimussuuntauksia, sekä toisaalta niitä käytännön johtopäätöksiä, joita alan tutkimus tuottaa työelämän vuorovaikutuksen kehittämiseen. Nostan esimerkkejä omasta tutkimuksestani virtuaalitiimien ja organisaatioiden sisäisen viestinnän ja vuorovaikutuksen näkökulmasta. 
Työelämän teknologiavälitteisen vuorovaikutuksen tutkimusperinteessä on nähtävissä kaksi vastakkaista suuntausta (ks. esim. Rice \& Leonardi, 2013). Toisaalta tutkimusta on hallinnut teknologinen determinismi, jossa on tutkittu teknologian vaikutuksia työelämälle yleensä laajasta, makrotason näkökulmasta. Tutkimuksissa on tarkasteltu teknologian vaikutuksia organisaatioiden valtasuhteisiin ja kontrolliin tai siihen, miten teknologia vaikuttaa organisaation hierarkiaan. Tämän perinteen tutkimus on keskittynyt teknologian ominaisuuksiin ja vaikutuksiin ja teknologian on nähty olevan se voima, joka vahvasti määrittää työelämässä tapahtuvia muutoksia ja prosesseja.

Toinen tälle vastakkainen teknologian tutkimuksen ääripää on niin sanottu sosiaalinen determinismi. Tässä tutkimussuuntauksessa teknologialle annetaan hyvin pieni rooli siinä, miten ihmiset työtä tekevät, ja työntekijöiden tulkinnat teknologiasta nostetaan kaikkein merkittävimpään rooliin. Sosiaalisuuden on nähty määrittävän tätä tutkimussuuntausta, koska monissa tämän ääripään tutkimuksissa kohteena olevaa teknologiaa ei aina edes kuvata tai tarkemmin määritellä. Sosiaalisen determinismin näkökulmasta teknologian vaikutukset eivät ole missään organisaatiossa tai tilanteessa samanlaisia, eikä ole olemassa teknologiaa, joka soveltuisi tiettyyn työelämän vuorovaikutustilanteeseen parhaalla mahdollisella tavalla.

Näiden ääripäiden välille on työelämän teknologiavälitteisen vuorovaikutuksen tutkimuksessa syntynyt kolmas tutkimusperinne, joka pyrkii ottamaan huomioon sekä teknologian käytön sosiaalisen puolen, että teknologian materiaaliset tai objektiiviset ominaisuudet. $\mathrm{Pu}$ hutaan sosiomateriaalisuudesta, joka tarkoittaa sitä, että teknologialla on tiettyjä ominaisuuksia, jotka mahdollistavat tai eivät mahdollista tietynlaista vuorovaikutusta. Työelämän näkö- kulmasta tämä tarkoittaa, että kullakin teknologialla tunnistetaan olevan tietyt erityispiirteet tai ominaisuudet, mutta työntekijät voivat mukautua teknologian käyttöön, tai teknologiaa voidaan käyttää eri tavoilla kuin mihin se on alun perin suunniteltu.

Tutkimuksessa onkin siirrytty tarkastelemaan teknologian vaikutusten sijaan sitä, mitä teknologiavälitteinen vuorovaikutus työelämässä mahdollistaa. Yksi tämän hetken keskeisiä tutkimuksen viitekehyksiä on teknologian affordanssinäkökulma. Näkökulma nojaa vahvasti sosiomateriaalisuuteen, ja se ottaa huomioon sekä teknologian objektiiviset ominaisuudet että vuorovaikutuksen, jota teknologia mahdollistaa (tai rajoittaa). Teknologisten affordanssien tai tarjoomien kautta on mahdollista selittää, miksi esimerkiksi työyhteisössä samaa teknologiaa voidaan käyttää eri tavoilla ja eri teknologioita samalla tavalla.

Näiden teoreettisten tutkimusnäkökulmien pohjalta haluaisin tuoda puheenvuoroni toisessa osiossa esiin muutaman käytännön esimerkin siitä, miten tutkimuksella voidaan kehittää työelämän teknologiavälitteistä vuorovaikutusta ja näin myös koko työelämää ja organisaatioita laajasti. Ensimmäinen esimerkkini pohjautuu virtuaalitiimien teknologiavälitteisen vuorovaikutuksen tutkimukseen ja toinen organisaatioiden sisäisen viestinnän ja vuorovaikutuksen tutkimiseen.

Virtuaalitiimit ovat tiimejä, joiden jäsenet ovat hajautuneet maantieteellisesti eri paikkoihin, ja jotka työskentelevät teknologiavälitteisesti, usein eri maista käsin, eri kulttuurien ja aikaerojen yli. Tekemämme kirjallisuuskatsauksen mukaan (Gibbs, Sivunen \& Boyraz, 2017) tällaisten tiimien tutkimuksessa keskeisiksi haasteiksi ovat nousseet tiimin johtajuus, viestinnälliset kulttuurierot ja niistä syntyvät jakolinjat ja 
alaryhmät virtuaalitiimien sisällä, sekä virtuaalitiimien käyttämä teknologia ja käytössä olevat viestintäkanavat. Teknologiavälitteisen vuorovaikutuksen tutkimuksella on pystytty vastaamaan moniin näistä virtuaalitiimien haasteista. Johtajuutta rakennetaan virtuaalitiimeissä teknologiavälitteisesti viesti viestiltä ja kokous kokoukselta tiimin jäsenten vuorovaikutuksen ja osallistumisaktiivisuuden kautta. Silti usein työelämän tiimeissä tarvitaan tutkimusten mukaan tehtävään nimettyä, tiiminvetäjän roolissa toimivaa johtajaa. Viestinnälliset kulttuurierot voivat korostua tiimin käyttämästä teknologiasta ja vuorovaikutusprosesseista riippuen, ja nämä erot voivat synnyttää konflikteja ja vahvistaa alaryhmiä näissä tiimeissä. Toisaalta teknologian käyttö voi yhdistää ja toimia positiivisesti yhteistä tiimi-identiteettiä luoden ja vahvistaen. Erilaiset teknologiat ja niiden sisältämät viestintäkanavat voivat myös edesauttaa ja rakentaa kokemusta sosiaalisesta läsnäolosta: siitä, että tiimin jäsenet kokevat olevansa yhdessä, samassa paikassa, vaikka työskentelevätkin toisistaan etäällä teknologian välityksellä. Toisaalta useat viestintäkanavat voivat myös haitata sosiaalisen läsnäolon kokemusta, hajottaa tarkkaavaisuutta ja vähentää läsnäolon tunnetta virtuaalikokouksissa. Koska virtuaalitiimien toiminta perustuu teknologiavälitteiseen vuorovaikutukseen, voi sen ympärillä tehtävä tutkimus konkreettisesti edesauttaa tällaisten tiimien työtä.

Toinen esimerkki työelämän teknologiavälitteisen viestinnän ja vuorovaikutuksen tutkimuksen sovellettavuudesta on yhdessä kollegoideni kanssa tehty tutkimukseni siitä, mitä erilaiset organisaation sisäiseen vuorovaikutukseen käytetyt teknologiat mahdollistavat (Rice ym. 2017). Tutkimme suuressa suomalaisessa media-alan organisaatiossa käytettyjä viestintävälineitä sähköpostista videoneuvotteluihin, puheluista tekstiviesteihin ja erilaisiin pikaviestimiin, ja kysyimme, millaisia toimintamahdollisuuksia nämä eri teknologiat työntekijöille tarjoavat. Vastausten perustella muotoutui kuusi organisaatioiden viestintäteknologiaa yhdistävää tarjoomaa tai affordanssia. Näitä tarjoomia olivat: 1) tiedon kaikkialle leviävyys, 2) muokattavuus, 3) haettavuus ja 4) näkyvyys, 5) itsensä esittäminen, sekä 6) tietoisuus muista ja muiden jakamasta tiedosta. Ensimmäinen, eli tiedon kaikkialle leviävyys tai läpitunkevuus tarkoittaa sitä, että viestintäteknologiaa on mahdollista käyttää työelämässä yhä useammalla eri päätelaitteella, ja tietoon pääsee käsiksi mistä ja milloin tahansa. Muokattavuus viittaa siihen, että tietoa voi muokata sen luomisen jälkeen. Esimerkiksi tekstiin pohjautuvia viestejä voi editoida vielä senkin jälkeen, kun ne on lähetetty. Haettavuus puolestaan tarkoittaa sitä, että tietoa voidaan hakea erilaisilla hakusanoilla ja metatiedolla eri järjestelmistä. Tiedon näkyvyys tarkoittaa, että työntekijät voivat saattaa käyttäytymisensä, mieltymyksensä sekä viestintäverkostonsa muille työntekijöille näkyväksi. Sellainen tieto, joka ilman teknologiaa olisi näkymätöntä, tai ainakin vaikeasti havaittavissa voidaan organisaation viestintäteknologian välityksellä tehdä nykyisin näkyväksi. Itsensä esittäminen viittaa siihen, että itsestään voi kertoa viestintäteknologian välityksellä siten kuin haluaa ja että omaa teknologiavälitteistä identiteettiään tai profiliaan voi muokata haluamaansa muotoon. Lopuksi tietoisuus teknologisena affordanssina viittaa siihen, että työntekijä pysyy teknologian kautta tietoisena organisaatiossa tai projektissa tapahtuvista ajankohtaisista asioista sekä kollegojensa tekemisistä ja mielipiteistä.

Mielenkiintoista on, että erityisesti sosiaalisen median on sanottu mahdollistavan sellaisia tarjoomia, jotka eivät ole aikaisemmin olleet mahdollisia kasvokkaisvuorovaikutuksessa tai edes muilla viestintävälineillä. Sosiaalinen media tekee näkyväksi esimerkiksi eri ihmisten 
ja asioiden väliset yhteydet. Se tuo ihmiset ja heidän jakamansa tiedon näkyviksi sekä näyttää ihmisten keskinäiset suhteet ja viestintäverkostot. Organisaatioiden sisäinen sosiaalinen media voisikin vahvistaa yhä hajautuneempien organisaatioiden toimintaa lisäämällä työntekijöiden tiedonjakoa ja tietoisuutta toisistaan myös virtuaalitiimeissä ja muissa uusissa työnteon muodoissa.

Sosiaalisen median työkalut ovat tulossa vahvasti osaksi työelämän vuorovaikutusta. Onkin kiinnostavaa nähdä, miten sosiaalisen median ominaispiirteitä ja mahdollisuuksia voidaan jatkossa hyödyntää työelämän teknologiavälitteisen vuorovaikutuksen kehittämisessä ja tutkimuksessa.

\section{Kirjallisuus}

Gibbs, J. L., Sivunen, A., \& Boyraz, M. (2017). Investigating the impacts of team type and design on virtual team processes. Human Resource Management Review 27(4), 590-603.

Rice, R. E., Evans, S. K., Pearce, K. E., Sivunen, A., Vitak, J., \& Treem, J. W. (2017). Organizational Media Affordances: Operationalization and Associations with Media Use. Journal of Communication, 67(1), 106-130.

Rice, R. E., \& Leonardi, P. M. (2013). Information and communication technology use in organizations. Teoksessa L.L. Putnam \& D.K. Mumby (toim.) The Sage Handbook of Organizational Communication, 425-448. Thousand Oaks, CA: Sage. 